\section{Evaluation of Viola Cultivars as Bedding Plants and Establishment of the Best-of- Class}

\author{
Richard O. Kelly, Zhanao Deng, and Brent K. Harbaugh
}

\begin{abstract}
ADDITIONAL INDEX WORDs. horned pansy, horned violet, miniature pansy, tufted
\end{abstract} pansy, Viola cornuta, variety trial

Summary. Florida is one of the top wholesale producers of bedding plants, and in 2003 was ranked fourth in the United States in annual bedding plant production and fifth in potted pansy (Viola $\times$ wittrockiana) and viola (V. cornuta) production. Evaluation of viola cultivars is vital for continued growth of the industry. We evaluated 66 viola cultivars in replicated class tests at the University of Florida's Gulf Coast Research and Education Center at Bradenton from 2000-04 and determined the best-of-class for use in future trials to compare against new entries in the same class. In this report, we provide objective plant measurements of vegetative and floral characteristics as well as subjective performance ratings. Viola cultivars were grouped into classes based on growth habit (standard vs. creeping), flower color, and flower color pattern, and the best cultivar in each class was determined. Cultivars with an outstanding overall performance rating (combined foliage, flower, arthropod feeding symptom, and disease symptom ratings $\geq 5.5$ out of a 7 high scale) for best-of-class selections were: (standard black class) 'Sorbet Black Delight'; (standard cream class) 'Velour Cream Splash'; (standard mix class) 'Babyface Mixture'; (standard orange with purple, red-violet cap class) 'Penny Orange Jump-Up'; [standard purple (dark), blue-violet with dark eye and light cap class] 'Angel Violet Blotch'; (standard white class) 'Penny White'; [standard white face with purple (dark), red-violet cap class] 'Skippy White With Violet Wing'; (standard yellow class) 'Jewel Lemon Yellow'; (standard yellow with blotch class) 'Babyface Yellow'; [standard yellow/white face with purple (dark), blue-violet cap class] 'Penny Classic Jump-Up'. Solitary cultivar entries (without comparison) with outstanding performance were: 'Angel Frosted Yellow Blotch', 'Angel Violet Duet', 'Babyface White', 'Eryln Purple Yellow', 'Four Seasons Yellow With Pink Wing', 'Gem Antique Apricot', 'Gem Antique Pink', 'Gem Antique Lavender', 'Hobbit Bilbo Baggins', 'Jewel Deep Blue', 'Penny Azure Twilight', 'Penny Beaconsfield', 'Penny Cream', 'Penny Orange', 'Penny Orchid Frost', 'Penny Purple', 'Penny Yellow Jump-Up', 'Princess Lavender and Yellow', 'Princess Purple and Gold', 'Rebel Yellow', 'Sorbet Coconut Swirl', 'Sorbet Icy Blue', 'Sorbet Lemon Swirl', 'Sparkler Purple Orange Face', and 'Sparkler Purple Wing'. These cultivars would likely perform well in the southern U.S. or areas of the world with similar heat and cold hardiness zones.

$\mathrm{V}$ iolas, also known as bedding pansies, miniature pansies, horned pansies, horned violet, or tufted pansy, are native to Spain and the Pyrenees Mountains (includes Andorra and southern and southwestern France). Violas comprise a genus that includes 500 species, with some species being utilized in the early 19 th century by William Thompson, an English gardener, to create today's hybrid pansies [Bailey, 1947; Texas A\&M, 1997; University of Wisconsin-Madison Botani-

University of Florida, IFAS, Environmental Horticulture Department, Gulf Coast Research and Education Center, 14625 CR 672, Wimauma, FL 33598

This research was supported by the Florida Agricultural Experiment Station, and approved for publication. We thank Joyce Jones, Nancy West, Gail Bowman, Paulette Blanton, and Jenna Adams for their excellent technical support. cal Garden, 2005; U.S. Department of Agriculture (USDA), 2004a].

Violas and pansies ranked third for wholesale value of flats ( $\$ 57$ million) and fourth for pots ( $\$ 19$ million) in the USDA 1998 Census of Horticultural Specialties (USDA, 1998). In 2003, the highest sales value to growers of bedding plants was attributed to geraniums (Pelargonium $\times$ hortorum $)(\$ 150$ million) with viola and pansy flats being second (\$118 million). The wholesale value for the number of potted violas and pansies produced in Florida in 2003 was $\$ 2.0$ million, ranking fifth in the U.S. (USDA, 2004b).

In the bedding plant industry, the competitive market seeks rapid dissemination of information through timely evaluations of new cultivars. $\mathrm{Ob}$ servational trials, as conducted by many universities, provide valuable information; however, they require replication over a number of years to equal the benefits provided by replicated trials. Growers need timely evaluations of performance that are not biased, since seed companies are frequently releasing new cultivars. Standards have not been developed for violas; thus, new cultivars are often compared with a random number of cultivars chosen from more than 150 cultivars currently available from a survey of eight major companies (R.O. Kelly, unpublished data). This study was done to evaluate viola cultivar performance in seasonal replicated trials to provide evaluations that may be used by the scientific community as well as by growers, landscapers, consumers, and seed companies. These trials were also used to identify cultivars to be used as standards (best-of-class) for comparing new cultivars as they become available without the need to reevaluate all older cultivars.

\section{Materials and methods}

Four trials were conducted between Dec. 2000 and Mar. 2004. The initial trial was concluded in 2001, evaluating 10 cultivars, and was used to establish best-of-class standards to be used as comparisons for new cultivar releases in future trials. Cultivars were placed into classes based on growth habit (standard vs. creeping), flower color, and flower color pattern, and all trial evaluations for each cultivar were grouped within that class by trial year (Tables 1 and 2). In all four trials there were multiple cultivar comparisons within some classes (Table l); however,

\begin{tabular}{llll}
\hline $\begin{array}{l}\text { Units } \\
\begin{array}{l}\text { To convert U.S. to SI, } \\
\text { multiply by }\end{array}\end{array}$ & U.S. unit & SI unit & $\begin{array}{l}\text { To convert SI to U.S., } \\
\text { multiply by }\end{array}$ \\
\hline 0.3048 & $\mathrm{ft}$ & $\mathrm{m}$ & 3.2808 \\
0.0929 & $\mathrm{ft}^{2}$ & $\mathrm{~m}^{2}$ & 10.7639 \\
2.5400 & inch $(\mathrm{es})$ & $\mathrm{cm}$ & 0.3937 \\
1.1209 & $\mathrm{lb} / \mathrm{acre}$ & $\mathrm{kg} \cdot \mathrm{ha}^{-1}$ & 0.8922 \\
28.3495 & $\mathrm{oz}$ & $\mathrm{g}$ & 0.0353 \\
$\left({ }^{\circ} \mathrm{F}-32\right) \div 1.8$ & ${ }^{\circ} \mathrm{F}$ & ${ }^{\circ} \mathrm{C}$ & $\left(1.8 \times{ }^{\circ} \mathrm{C}\right)+32$
\end{tabular}


Table 1. Plant and flowering characteristics and performance ratings for violas grown in four winter/spring trials from 2000-04 in Bradenton, Fla., grouped within classes according to flower color.

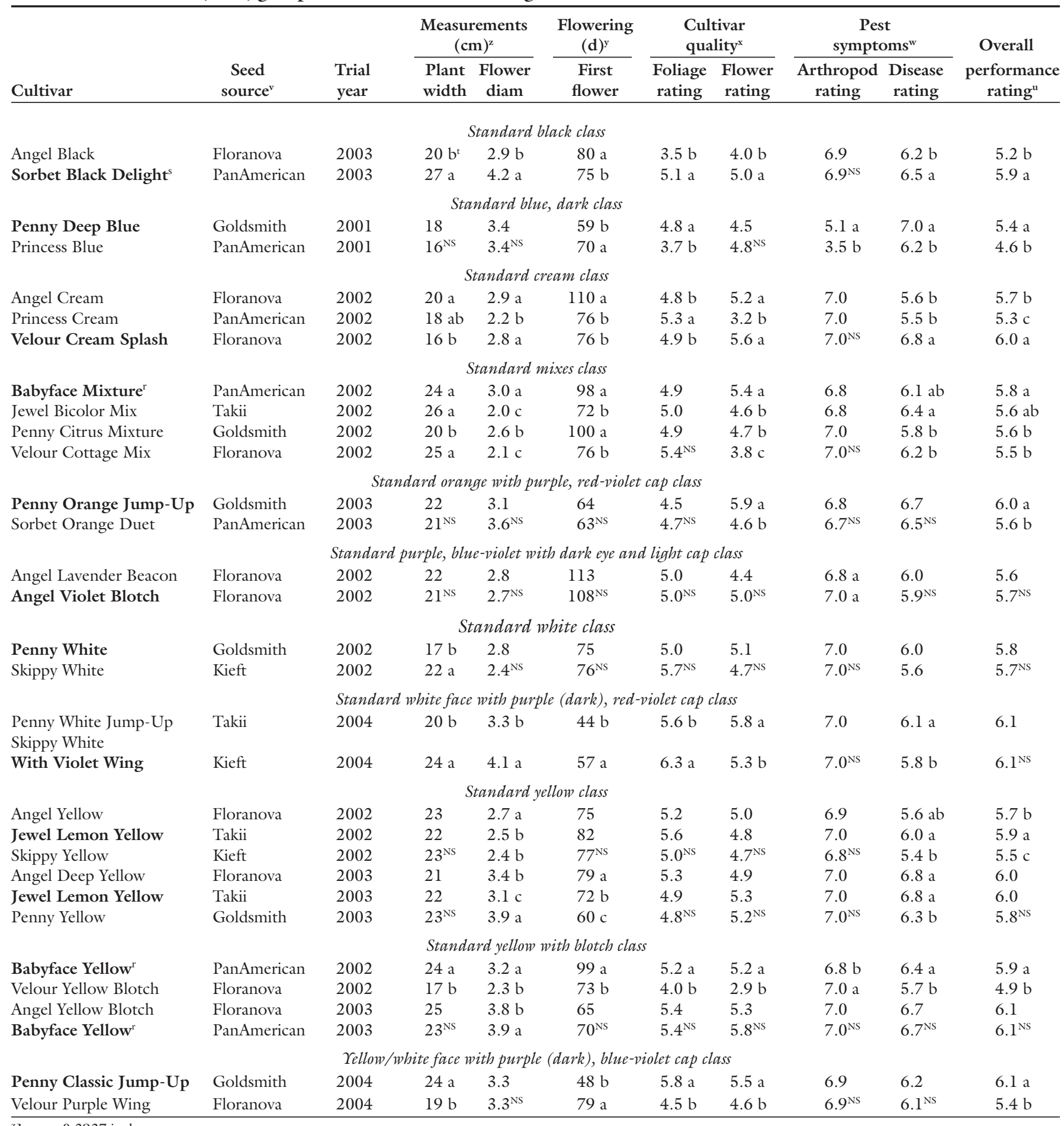

${ }^{\mathrm{z}} 1 \mathrm{~cm}=0.3937$ inch.

yThe number of days from sowing seed to the unfurling of the first flower in a plot.

xAverage of all foliage or flower quality ratings taken during the evaluation period on a scale of 1 to 7 with 7 excellent.

wAverage of all arthropod or disease ratings for flowers (foliage pest-free) taken during the evaluation period on a scale of 1 to 7 , with $7=$ all flowers in a plot were free from arthropod feeding or plant disease symptoms; no foliage pests observed.

'Seed Sources: Floranova = Floranova Services, Litchfield, Mich.; Goldsmith = Goldsmith Seeds, Gilroy, Calif.; Kieft $=$ Kieft Seeds Holland, Conway, Wash; PanAmerican = PanAmerican Seed Co., West Chicago Ill.; Takii = American Takii, Salinas, Calif.

"Overall performance rating is the average of the foliage, flower, arthropod, and disease ratings.

'Mean separation within classes by Duncan's multiple range test at $P<0.05$.

${ }^{s}$ Best-of-class (bold type) chosen from the overall performance rating or by another rating, if overall performance values were equal.

r'Babyface Mixture' and 'Babyface Yellow' were renamed 'Sorbet Babyface Mixture' and 'Sorbet Babyface Yellow'

"Nonsignificant. 
Table 2. Plant and flowering characteristics and performance ratings for stand-alone viola ${ }^{z}$ cultivars grown in four winter/ spring trials from 2000-04 in Bradenton, Fla.

\begin{tabular}{|c|c|c|c|c|c|c|c|c|c|c|}
\hline \multirow[b]{2}{*}{ Cultivar } & \multirow[b]{2}{*}{$\begin{array}{c}\text { Seed } \\
\text { source }^{\mathrm{u}}\end{array}$} & \multirow[b]{2}{*}{$\begin{array}{l}\text { Trial } \\
\text { year }\end{array}$} & \multicolumn{2}{|c|}{$\begin{array}{l}\text { Measurements } \\
\qquad(\mathrm{cm})^{\mathrm{y}}\end{array}$} & \multirow{2}{*}{$\begin{array}{c}\begin{array}{c}\text { Flowering } \\
(d)^{x}\end{array} \\
\text { First } \\
\text { flower }\end{array}$} & \multicolumn{2}{|c|}{$\begin{array}{l}\text { Cultivar } \\
\text { quality }^{\mathrm{w}}\end{array}$} & \multicolumn{2}{|c|}{$\begin{array}{c}\text { Pest } \\
\text { symptoms }^{v}\end{array}$} & \multirow{2}{*}{$\begin{array}{c}\text { Overall } \\
\text { performance } \\
\text { rating }^{\mathrm{t}}\end{array}$} \\
\hline & & & $\begin{array}{l}\text { Plant } \\
\text { width }\end{array}$ & $\begin{array}{c}\text { Flower } \\
\text { diam }\end{array}$ & & $\begin{array}{c}\text { Foliage } \\
\text { rating }\end{array}$ & $\begin{array}{c}\text { Flower } \\
\text { rating }\end{array}$ & $\begin{array}{c}\text { Arthropod } \\
\text { rating }\end{array}$ & $\begin{array}{c}\text { Disease } \\
\text { rating }\end{array}$ & \\
\hline \multicolumn{11}{|l|}{ Angel Frosted } \\
\hline Yellow Blotch & Floranova & 2003 & $23 \pm 1.3$ & $4.2 \pm 0.1$ & $74 \pm 2.4$ & $5.6 \pm 0.2$ & $4.2 \pm 0.2$ & $7.0 \pm 0.1$ & $6.7 \pm 0.1$ & $5.9 \pm 0.1$ \\
\hline Angel Red & Floranova & 2002 & $20 \pm 4.7$ & $3.3 \pm 0.1$ & $114 \pm 1.5$ & $3.8 \pm 0.0$ & $3.0 \pm 0.0$ & $6.2 \pm 0.3$ & $5.2 \pm 0.2$ & $4.6 \pm 0.2$ \\
\hline Angel Violet Duet & Floranova & 2002 & $23 \pm 0.8$ & $2.7 \pm 0.1$ & $90 \pm 21.7$ & $5.3 \pm 0.4$ & $5.0 \pm 0.3$ & $6.4 \pm 0.2$ & $5.4 \pm 0.3$ & $5.5 \pm 0.2$ \\
\hline Babyface White $^{\mathrm{s}}$ & PanAmerican & 2002 & $21 \pm 1.2$ & $2.7 \pm 0.2$ & $101 \pm 1.0$ & $4.9 \pm 0.2$ & $4.4 \pm 0.2$ & $7.0 \pm 0.0$ & $5.4 \pm 0.1$ & $5.5 \pm 0.1$ \\
\hline Eryln Purple Yellow & Kieft & 2003 & $31 \pm 3.0$ & $3.0 \pm 0.2$ & $66 \pm 1.9$ & $5.3 \pm 0.3$ & $4.7 \pm 0.0$ & $6.7 \pm 0.1$ & $6.3 \pm 0.0$ & $5.8 \pm 0.1$ \\
\hline \multicolumn{11}{|l|}{ Four Seasons Yellow } \\
\hline With Pink Wing & Sahin & 2003 & $25 \pm 1.0$ & $3.3 \pm 0.1$ & $72 \pm 1.4$ & $5.5 \pm 0.5$ & $4.3 \pm 0.3$ & $7.0 \pm 0.0$ & $6.5 \pm 0.0$ & $5.8 \pm 0.2$ \\
\hline Gemini Purple and Yellow & Sakata & 2001 & $24 \pm 2.6$ & $3.6 \pm 0.1$ & $60 \pm 1.8$ & $5.7 \pm 0.4$ & $3.9 \pm 0.4$ & $4.8 \pm 0.4$ & $6.5 \pm 0.2$ & $5.2 \pm 0.2$ \\
\hline Hobbit Bilbo Baggins & Sahin & 2003 & $24 \pm 0.9$ & $3.7 \pm 0.1$ & $79 \pm 2.4$ & $5.5 \pm 0.2$ & $4.0 \pm 0.2$ & $7.0 \pm 0.0$ & $6.8 \pm 0.2$ & $5.7 \pm 0.1$ \\
\hline Jewel Deep Blue & Takii & 2002 & $23 \pm 0.8$ & $2.4 \pm 0.1$ & $84 \pm 4.7$ & $5.6 \pm 0.2$ & $5.8 \pm 0.2$ & $6.9 \pm 0.1$ & $6.4 \pm 0.1$ & $6.1 \pm 0.2$ \\
\hline Penny Azure Twilight & Goldsmith & 2003 & $19 \pm 1.8$ & $3.6 \pm 0.2$ & $62 \pm 2.4$ & $5.0 \pm 0.5$ & $6.2 \pm 0.2$ & $6.8 \pm 0.1$ & $6.4 \pm 0.1$ & $6.1 \pm 0.1$ \\
\hline Penny Beaconsfield & Goldsmith & 2003 & $23 \pm 1.4$ & $4.1 \pm 0.2$ & $66 \pm 1.3$ & $5.1 \pm 0.4$ & $4.6 \pm 0.5$ & $7.0 \pm 0.0$ & $6.8 \pm 0.2$ & $6.9 \pm 0.3$ \\
\hline Penny Cream & Goldsmith & 2003 & $20 \pm 1.0$ & $3.8 \pm 0.3$ & $70 \pm 1.5$ & $4.6 \pm 0.5$ & $4.3 \pm 0.7$ & $6.9 \pm 0.1$ & $6.7 \pm 0.0$ & $5.6 \pm 0.2$ \\
\hline Penny Orange & Goldsmith & 2003 & $18 \pm 1.1$ & $3.9 \pm 0.1$ & $68 \pm 5.2$ & $4.4 \pm 0.4$ & $4.0 \pm 0.5$ & $6.8 \pm 0.0$ & $6.3 \pm 0.0$ & $5.4 \pm 0.2$ \\
\hline Penny Orchid Frost & Goldsmith & 2001 & $19 \pm 0.7$ & $3.3 \pm 0.1$ & $60 \pm 1.3$ & $5.3 \pm 0.4$ & $5.3 \pm 0.0$ & $6.9 \pm 0.2$ & $6.4 \pm 0.4$ & $6.0 \pm 0.2$ \\
\hline Penny Purple & Goldsmith & 2002 & $21 \pm 2.6$ & $3.0 \pm 0.2$ & $78 \pm 2.3$ & $5.3 \pm 0.4$ & $5.3 \pm 0.2$ & $6.8 \pm 0.0$ & $5.3 \pm 0.3$ & $5.6 \pm 0.1$ \\
\hline Penny Yellow Jump-Up & Goldsmith & 2001 & $20 \pm 1.7$ & $3.1 \pm 0.2$ & $59 \pm 1.7$ & $5.0 \pm 0.2$ & $5.0 \pm 0.3$ & $5.1 \pm 0.2$ & $6.9 \pm 0.2$ & $5.5 \pm 0.1$ \\
\hline Princess Lavender Yellow & PanAmerican & 2001 & $19 \pm 0.7$ & $3.0 \pm 0.1$ & $71 \pm 2.1$ & $4.7 \pm 0.2$ & $4.8 \pm 0.2$ & $6.8 \pm 0.2$ & $7.0 \pm 0.0$ & $5.8 \pm 0.1$ \\
\hline Sorbet Icy Blue & PanAmerican & 2004 & $22 \pm 0.8$ & $3.8 \pm 0.2$ & $60 \pm 2.3$ & $5.7 \pm 0.2$ & $5.9 \pm 0.1$ & $7.0 \pm 0.0$ & $6.7 \pm 0.0$ & $6.3 \pm 0.1$ \\
\hline Sorbet Lemon Swirl & Ball & 2001 & $19 \pm 1.8$ & $3.4 \pm 0.1$ & $55 \pm 0.5$ & $5.4 \pm 0.3$ & $4.7 \pm 0.2$ & $6.2 \pm 0.4$ & $6.5 \pm 0.2$ & $5.7 \pm 0.2$ \\
\hline \multicolumn{11}{|l|}{ Sparkler Purple } \\
\hline Orange Face & Floranova & 2003 & $18 \pm 0.4$ & $3.3 \pm 0.2$ & $73 \pm 1.7$ & $4.7 \pm 0.3$ & $5.2 \pm 0.2$ & $6.6 \pm 0.4$ & $6.5 \pm 0.0$ & $5.8 \pm 0.3$ \\
\hline Sparkler Purple Wing & Floranova & 2003 & $25 \pm 1.5$ & $4.0 \pm 0.2$ & $83 \pm 2.9$ & $5.0 \pm 0.5$ & $3.8 \pm 0.4$ & $6.7 \pm 0.1$ & $6.2 \pm 2.1$ & $5.5 \pm 0.3$ \\
\hline \multicolumn{11}{|l|}{ Sparkler Purple } \\
\hline Yellow Face & Floranova & 2003 & $23 \pm 0.9$ & $3.7 \pm 0.2$ & $92 \pm 1.0$ & $4.2 \pm 0.2$ & $4.2 \pm 0.2$ & $6.7 \pm 0.0$ & $6.0 \pm 0.3$ & $5.3 \pm 0.0$ \\
\hline Skippy Purple & Kieft & 2002 & $24 \pm 1.0$ & $2.7 \pm 0.1$ & $85 \pm 11.7$ & $5.5 \pm 0.4$ & $4.3 \pm 0.4$ & $6.5 \pm 0.0$ & $5.2 \pm 0.2$ & $5.3 \pm 0.2$ \\
\hline Velour Blue Bronze & Floranova & 2002 & $20 \pm 1.0$ & $2.7 \pm 0.3$ & $65 \pm 1.5$ & $4.2 \pm 0.5$ & $2.9 \pm 0.2$ & $6.4 \pm 0.4$ & $5.1 \pm 0.3$ & $4.6 \pm 0.1$ \\
\hline
\end{tabular}

${ }^{2}$ Uncontested best-of-class: cultivars with unique colors without comparison, or that had no other entries in their class for comparison in our trials.

y $1 \mathrm{~cm}=0.3937$ inch.

The number of days from sowing seed to the unfurling of the first flower in a plot.

wAverage of all foliage or flower quality ratings taken during the evaluation period on a scale of 1 to 7 with 7 excellent.

vAverage of all arthropod or disease ratings for flowers (foliage pest-free) taken during the evaluation period on a scale of 1 to 7 with $7=$ all flowers in a plot were free from arthropod feeding or plant disease symptoms; no foliage pests observed.

"Seed sources: Ball $=$ Ball Seed Co., West Chicago, Ill.; Floranova $=$ Floranova Services, Litchfield, Mich.; Goldsmith $=$ Goldsmith Seeds, Gilroy, Calif.; Kieft $=$ Kieft Seeds Holland, Conway, Wash; PanAmerican = PanAmerican Seed Co., West Chicago Ill.; Sahin = K. Sahin (North America), Vista, Calif.; Sakata = Sakata Seed America, Morgan Hill, Calif.; Takii = American Takii, Salinas, Calif.

tOverall performance rating is the average of the foliage, flower, arthropod, and disease ratings.

s'Babyface White' was renamed 'Sorbet Babyface White' and genetics are unchanged. 
many cultivars evaluated were the sole entry for a class (stand-alones; Table 2 ). If two cultivars from the same class were not evaluated in the same trial, they will be reevaluated together in a future trial to resolve best-of-class. Twenty-nine, 19, and four new cultivars were evaluated in 2002, 2003, and 2004 , respectively.

Seeds were sown in seeder trays (model P-Seed20; Landmark Plastic Corp., Akron, Ohio) $21.5 \times 11 \times 2.4$ inches on 4-5 Dec. 2000, 4 Oct. 2001, 10 and 14 Oct. 2002, and 6, 20-21 Oct. 2003 (latter 2003 dates included all cultivars within the same class). Germination occurred between 72 to $75^{\circ} \mathrm{F}$ in a growth room with a photosynthetic photon flux $(P P F)$ of $30 \mathrm{umol} \cdot \mathrm{m}^{-2} \cdot \mathrm{s}^{-1}$ for $24 \mathrm{~h}$ from cool-white fluorescent lamps. Immediately after germination, seedlings were transplanted into Todd planter flats (model 128; Speedling, Sun City, Fla.) $1.5 \times 1.5 \times 2.5$ inches, and grown to mature, nonflowering plugs on 4 Dec. 2000 to 1 Feb. 2001, 4 Oct. to 29 Nov. 2001,10 Oct. to 11 Dec. 2002 in a fiberglass-covered, screen-sided greenhouse with a $P P F$ ranging from 800 to $1200 \mu \mathrm{mol} \cdot \mathrm{m}^{-2} \cdot \mathrm{s}^{-1}$ at ambient temperature, and in a cooled greenhouse with a $P P F$ ranging from 800 to $1000 \mathrm{umol} \cdot \mathrm{m}^{-2} \cdot \mathrm{s}^{-1}$ and a temperature ranging from 60 to $90{ }^{\circ} \mathrm{F}$ on 6 Oct. to 24 Nov. 2003. Before transplanting into the field, flats were placed outside in full sun for 1 to 2 weeks for hardening. Plugs were transplanted on 31 Jan. to I Feb. 2001, 27 to 29 Nov. 2001, 11 Dec. 2002, and 17 to 24 Nov. 2003 into raised ground beds 32 inches wide $\times 8$ inches high of EauGallie fine sand ( $\mathrm{pH}$ range $=6.2$ to 6.8). Six plants per plot were spaced 9 inches apart and arranged from the bed center in two, three-plant rows across the bed width for a $2-\mathrm{ft}^{2}$ plot with an equal area between plots.

Solid Nutricote 13-13-13 fertilizer $(13 \mathrm{~N}-5.7 \mathrm{P}-10.8 \mathrm{~K}, 100-\mathrm{d}$ slowrelease type; Florikan, Sarasota, Fla.) fertilizer was applied by hand to each plant on the soil surface about 1 inch from the plant stem under the plastic mulch in 2000-01 and 2001-02 at 0.5 oz per plant. Osmocote Plus 15-9-12 fertilizer $(15 \mathrm{~N}-3.9 \mathrm{P}-10 \mathrm{~K})$ slow-release type (5-6 months) with micronutrients (Scotts Co., Marysville, Ohio) was used at the same rate in 2002-03 and 2003-04. Beds were fumigated $\geq 14 \mathrm{~d}$ before planting with a mixture of $66 \%$ methyl bromide and 33\% chlo- ropicrin at $350 \mathrm{lb} /$ acre and covered with white-on-black polyethylene film. Seepage irrigation water was supplied from lateral ditches spaced $40.5 \mathrm{ft}$ apart (Howe and Waters, 1989).

Integrated pest management was employed to determine when pesticide applications were needed to control arthropod pests and plant pathogens. Weather information was recorded by an automated weather station at the University of Florida's Gulf Coast Research and Education Center at Bradenton (lat. $27^{\circ} 4^{\prime} \mathrm{N}$, long. $82^{\circ} 5^{\prime} \mathrm{W}$ ) [American Horticultural Society (AHS) Heat Zone 10 (AHS, 1999); USDA Cold Hardiness Zone 9b) (U.S. National Arboretum, 1990)].

Plant height (from the stem base to the inflorescence tip), plant width at the widest point, and flower diameter were recorded for three plants selected from the center and edge of each plot between 14-15 Mar. 2001, on 15 Feb. 2002, between 5-6 Feb. 2003, and on 26 Jan. 2004. Subjective ratings were made by the senior author between 28 Feb. and 10 Apr. 2001, 16 Jan. and 2 Mar. 2002, 15 Jan. to 29 Mar. 2003, and 7 Jan. to 5 Mar. 2004 (evaluations were across all six plants, resulting in one value per plot). A 1 to 7 rating scale was used with the highest rating a 7 . Floral characteristics were rated within a scale as follows: 7 = flowers numerous, uniformly distributed over all plants, flowers were free from pest symptoms; 4 = average floral display, may have some pest damage but not severe enough to cause flowers to be unacceptable; and 1 = unacceptable flower number or display, and/or pest damage severe, resulting in unattractive flowers. Foliage ratings were as follows: 7 = all plants in a plot had full and uniform foliage, plants were free of pest symptoms and abnormalities or weaknesses such as lodging; $4=$ average foliage density, minimal lodging, and/or some insect damage but foliage was still acceptable; 1 = foliage sparse, stem lodging, and/or unacceptable pest damage making plants undesirable. Arthropod and disease ratings on flowers were as follows: 7 = all flowers free from arthropod feeding scars and absence of diseased tissue in the form of spots, blights, or tissue distortion caused by a pathogen; $4=$ minimal pest damage to tissue, and flowers still acceptable; $\mathrm{l}=$ flowers severely infested and damaged, resulting in undesirable flowers. For a measure of performance over time, ratings were added and divided by the total number of ratings (two to four per trial). For a measure of overall performance, flower, foliage, arthropod, and disease ratings were added and divided by four. For each class, the cultivar with the highest overall performance rating was selected as best-of-class. If the overall performance rating was a tie, another rating was chosen to determine best-of-class. These cultivars were then used in trials 2 to 4 as the "standard" for comparison of new cultivars in their class.

Each class was analyzed as a separate experiment. A randomized complete-block experimental design was used with three or four blocks containing six plants per plot. The experimental unit for objective data was the average measurement from three plants, and for subjective data, one rating value considering all six plants in the plot. All data were analyzed by analysis of variance (ANOVA) methods, and means of dependent variables significant at the 0.05 level of probability were separated using Duncan's multiple range test (PROC ANOVA; SAS Institute, Cary, N.C.).

\section{Results and discussion}

The four trials had average monthly temperatures that ranged from $12.1^{\circ} \mathrm{C}$ in Jan. 2003 to $22.1^{\circ} \mathrm{C}$ in Mar. 2003. Temperature extremes were $-2.49^{\circ} \mathrm{C}$ (Jan. 2003) and 31.7 ${ }^{\circ} \mathrm{C}$ (Mar. 2002), respectively. No rainfall fell in Nov., Feb., and Apr. 2001, while 10.8 inches fell in Mar. 2001 (Florida Automated Weather Network, 2004).

Flowers were damaged every season by two pests: thrips (Frankliniella spp.) and graymold (Botrytis cinerea).

Table 1 presents the best-of-class for each class, with the trial year it was selected. Solitary cultivar entries without comparison are listed in Table 2. Plant width, flower size, and flowering earliness are listed in Tables 1 and 2 . One or more of these characteristics may be the criteria for selection used by some in the selection process, outweighing seasonal performance. It is also important to note that cultivars can be selected as best-of-class and have poor to outstanding performance ratings. Cultivars with an overall rating $>5.5$ were considered outstanding, 5.0-5.4 as good, 4.0-4.9 as fair, and $<4.0$ as poor. 


\section{Establishment of best-of-class cultivars}

STANDARD BLACK CLASS. In 2003, 'Sorbet Black Delight' was best-of-class with an overall performance rating of 5.9 compared to 5.2 for 'Angel Black'.

Standard blue (DARK) Class. 'Penny Deep Blue' was established as best-of-class in 2001 with an overall performance rating of 5.4 compared to 4.6 for 'Princess Blue'.

STANDARD CREAM CLASS. In 2002 , 'Angel Cream' had a rating of 5.7 compared to 5.3 for 'Princess Cream', while 'Velour Cream Splash' had a rating 6.0 to become best-of-class.

STANDARD MIX Class. In 2002, 'Babyface Mixture' became best-ofclass with an overall performance rating of 5.8 compared to 'Penny Citrus Mixture' 5.6 and 'Jewel Bicolor Mix', while 'Velour Cottage Mix' had a rating of 5.5 .

STANDARD ORANGE WITH PURPLE, RED-VIOLET CaP Class. 'Penny Orange Jump-Up' was established as best-ofclass in 2001 with an overall performance rating of 5.6. In 2003, 'Penny Orange Jump-Up' had a rating of 6.0, compared to 5.6 for 'Sorbet Orange Duet', to remain best-of-class.

STANDARD PURPLE (DARK), BLUEVIOLET WITH DARK EYE AND LIGHT CAP ClASs. 'Angel Violet Blotch' was established as best-of-class in 2002 with an overall performance rating of 5.7 compared to 5.6 for 'Angel Lavender Beacon'.

STANDARD WHITE CLASS. In 2002 , 'Penny White' had a rating of 5.8 compared to 5.7 for 'Skippy White', to become best of class.

STANDARD WHITE FACE WITH PURPLE (DARK), RED-VIOLET CAP CLASS. In 2004, 'Skippy White With Violet Wing' and 'Penny White Jump-Up' had a rating of 6.1, while 'Skippy White With Violet Wing' was chosen bestof-class, based on a higher combined foliage and flower rating average of 5.8 for cultivar quality, compared with 5.7 for 'Penny White Jump-Up'.

STANDARD YELLOW ClASS. In 2002, 'Jewel Lemon Yellow' was selected best-of-class with a rating of 5.9 compared to 5.7 for 'Angel Yellow' and 5.5 for 'Skippy Yellow'. In 2004, 'Jewel Lemon Yellow' and 'Angel Deep Yellow' both had an overall performance rating of 6.0 compared to 5.8 for 'Penny Yellow', and both had an equal combined foliage flower rating of 5.1; 'Jewel Lemon Yellow' retained best-of-class ranking based on a higher average flower rating of 5.3 , compared to 4.9 for 'Angel Deep Yellow' and 5.2 for 'Penny Yellow'.

STANDARD YELLOW WITH BLOTCH CLAss. 'Babyface Yellow' was established as best-of-class in 2002 with an overall performance rating of 5.9 compared to 4.9 for "Velour Yellow Blotch'. In 2003, 'Babyface Yellow' and 'Velour Yellow Blotch' had an overall performance rating of 6.2 , while 'Babyface Yellow' remained bestof-class with a combined foliage and flower quality rating of 5.6 compared to 5.3 for 'Velour Yellow Blotch'.

STANDARD Yellow/White FaCe WITH PURPLE (DARK), BLUE-VIOLET CAP CLAss. In 2004, 'Penny Classic JumpUp' had a rating of 6.1 compared to 5.4 for 'Velour Purple Wing', replacing 'Velour Purple Wing' as best of class.

\section{Selecting outstanding cultivars}

The standard for comparison (best-of-class) used against new viola releases in future trials will be based on the highest overall performance rating for cultivars in the same class (regardless of relative performance) to eliminate the need for reevaluation of numerous cultivars. Ideally, best-of-class viola selections with outstanding ratings are desired. Other viola cultivars in a class may have statistically similar overall performance ratings, but the rating value may be lower. Cultivars with an outstanding overall performance rating for best-of-class were: 'Angel Violet Blotch', 'Babyface Mixture', 'Babyface Yellow', 'Jewel Lemon Yellow', 'Penny Classic Jump-Up', 'Penny Orange Jump-Up', 'Penny White', 'Skippy White With Violet Wing', 'Sorbet Black Delight', and 'Velour Cream Splash'. Cultivars that were outstanding, but not best-of-class were 'Penny Citrus Mix', 'Angel Deep Yellow', 'Angel Lavender Beacon', 'Angel Yellow', 'Angel Yellow Blotch', 'Jewel Bicolor Mix', 'Penny White Jump-Up', 'Penny Yellow', 'Skippy White', 'Skippy Yellow', 'Sorbet Orange Duet', and 'Velour Cottage Mix'.

Solitary cultivar entries with an outstanding overall performance rating were: 'Angel Frosted Yellow Blotch', 'Angel Violet Duet', 'Babyface White', 'Eryln Purple Yellow', 'Four Seasons
Yellow With Pink Wing', 'Gem Antique Apricot', 'Gem Antique Pink', 'Gem Antique Lavender', 'Hobbit Bilbo Baggins', 'Jewel Deep Blue', 'Penny Azure Twilight', 'Penny Beaconsfield', 'Penny Cream', 'Penny Orange', 'Penny Orchid Frost', 'Penny Purple', 'Penny Yellow Jump-Up', 'Princess Lavender and Yellow', 'Princess Purple and Gold', 'Rebel Yellow' 'Sorbet Coconut Swirl', 'Sorbet Icy Blue', 'Sorbet Lemon Swirl', 'Sparkler Purple Orange Face', and 'Sparkler Purple Wing'.

\section{Literature cited}

American Horticulture Society. 1999. Heat zone map. 30 Sept. 2005. <http://www. ahs.org/publications/heat_zone_map. htm>.

Bailey, L.H. 1947. The standard cyclopedia of horticulture. Macmillan, New York.

Florida Automated Weather Network. 2004. FAWN: Report generator. 23 June 2005. <http://fawn.ifas.ufl.edu/scripts/ reportrequest.asp $>$.

Howe, T.K. and W.E. Waters. 1989. Pansy cultivar evaluation in the landscape. Proc. Fla. State Hort. Soc. 102:97-101.

Texas A\&M University. 1997. PLANTanswers information about flowers: Pansy. 30 Sept. 2005. <http://aggie-horticulture. tamu.edu/plantanswers/flowers/pansies. html>.

University of Wisconsin-Madison Botanical Garden. 2005. Species detail page: Viola cornuta. 30 Sept. 2005. <http://www. botany.wisc.edu/garden/db/speciesdetail asp? genus $=$ Viola\&species $=$ cornuta $>$.

U.S. Department of Agriculture. 1998. 1998 Census of horticultural specialties: Annual bedding/garden plants sold for the United States. USDA, Natl. Agr. Stat. Serv. 30 Sept. 2005. <http://www.nass. usda.gov/census/census97/horticulture/ table04-07.pdf>.

U.S. Department of Agriculture. 2004a. Data from GRIN taxonomy: Taxon: Viola cornuta L. U.S. Dept. Agr., Agr. Res. Serv., Germplasm Resources Info. Network, Natl. Genet. Resources Prog. 30 Sept. 2005. <http://www.ars-grin.gov/cgibin/npgs/html/taxon.pl?41704>.

U.S. Department of Agriculture. 2004b. Floricultural crops 2003 summary. U.S. Dept. Agr., Natl. Agr. Stat. Serv., Washington, D.C.

U.S. National Arboretum. 1990. USDA plant hardiness zone map. 30 Sept. 2005. <http://www.usna.usda.gov/Hardzone/ ushzmap.html>. 